DOI: $10.21802 /$ artm.2019.4.12.128.

УДК $612.66+612.821 .2+613.955+612.392 .4+546.15$

\title{
ВІКОВІ ТА ГЕНДЕРНІ ОСОБЛИВОСТІ КОГНІТИВНИХ ФУНКЦІЙ У ДІТЕЙ ШКІЛЬНОГО ВІКУ ІЗ ЛЕГКИМ ЙОДОДЕФЦЦИТОМ ТА ЛАТЕНТНИМ ЗАЛІЗОДЕФІЦИТОМ
}

\author{
У.П. Шаламай
}

Івано-Франківський національний медичний університет, кафедра фізіології,

м. Івано-Франківськ, Украӥна,

ORCID ID: 0000-0001-7044-3585,

e-mail:fap12710@gmail.com

Резюме. Актуальність дослідження зумовлена поширеністю йодо- та залізодефіцитних станів в Україні. Нестача заліза в ранньому дитинстві призводить до затримки мовних навичок, зниження коефіцієнта інтелекту (IQ), здатності до навчання. У підлітковому віці дефіцит заліза супроводжується погіршенням пам'яті, адаптаційних можливостей центральної нервової системи. Недостатній уміст йоду в раціоні харчування зумовлює порушення тиреоїдного гомеостазу, особливо в дитячому віці, що призводить до затримки психічного та фізичного розвитку дітей. У статті представлені результати дослідження психофізіологічного розвитку 133 школярів віком 6-18 років із належним йодо- та залізозабезпеченням (контрольна група), латентним залізодефіцитом, легким йододефіцитом та за умов їх поєднання. Для оцінки когнітивних функцій у школярів визначали коефіцієнт інтелекту, проводили коректурну пробу (визначали швидкість опрацювання інформації, коефіцієнти точності виконуваної роботи та стійкості уваги); досліджували показники темпу сенсорних реакцій та особливостей уваги (психічну стійкість, ефективність роботи, ступінь включення в роботу) за модифікованими таблицями Шульте.

Установлено, що дефіцит мікроелементів (заліза та йоду) зумовлює порушення когнітивних функцій, особливо при комбінованому ї впливі. У таких дітей встановлено зниження коефіцієнта інтелекту у 74 \% обстежених (нижче 90 ум.од.), зниження ефективності роботи на $48 \%$ ( $<0,05)$, ступеня включення в роботу на $32 \%(\mathrm{p}<0,05)$, швидкості опрацювання інформацій на $46 \%$ ( $<0,01)$, коефіцієнта стійкості уваги на $36 \%$ $(\mathrm{p}<0,05)$ та збільшення кількості дітей із нестійкою кривою виснаження. Ступінь психофізіологічних порушень залежить від віку (більш чутливі діти молодшого віку), статі (більше схильні дівчата) та генезу мікроелементозу (суттєвіші порушення виявленні при комбінованому йодо- та залізодефіциті).

Ключові слова: когнітивні функції, латентний залізодефіцит, легкий йододефіцит, діти шкільного віку.

Вступ. Збалансоване харчування є одним із важливих факторів, які впливають на здоров'я дитини. Через інтенсивний ріст дитячий організм потребує в раціоні більшу кількість мікроелементів (заліза, йоду, селену та інш.) $[6,14]$. Недостатнє надходження біоелементів у дитячий організм негативно впливає на психічний, фізичний та статевий розвиток, знижує адаптаційні резерви організму і порушує обмінні процеси $[1,12]$. В Україні зареєстровано понад 1,5 млн. хворих на тиреоїдину патологію, із них майже 500 тисяч дітей, залізодефіцитні стани має понад третина населення $[9,14]$. У той же час поширеність залізодефіцитної анемії та йододефіцитних станів у деяких регіонах може свідчити про високу ймовірність утворення комбінованого дефіциту йоду та заліза.

Обгрунтування дослідження. Експериментально доведено, що дефіцит заліза призводить до порушення енергетичного обміну, окисно-відновних процесів у центральній нервовій системі та мієлінізації нервових волокон [11]. Установлено, що нестача заліза в ранньому дитинстві призводить до затримки мовних навичок, зниження коефіцієнта інтелекту (IQ), здатності до навчання $[8,12]$. У підлітковому віці дефіцит заліза супроводжується погіршенням пам'яті, адаптаційних можливостей центральної нервової системи $[5,13]$. Недостатній уміст йоду в раціоні харчування зумовлює порушення тиреоїдного гомеостазу, особливо в дитячому віці, яке призводить до затримки психічного та фізичного розвитку дітей $[2,15]$. Понад $2 / 3$ дітей, які проживають у регіонах із дефіцитом йоду у довкіллі, мають відхилення інтелектуального розвитку (у них IQ нижче на 10-15 пунктів, ніж у однолітків без йододефіциту) [3]. Зважаючи на поширеність йодо- та залізодефіциту на території України, доцільно вивчити їх комбінований вплив на когнітивні функції дітей шкільного віку.

Мета дослідження - вивчити вплив легкого йододефіциту та латентного залізодефіциту на когнітивні функції дітей шкільного віку.

Матеріали та методи дослідження. Для досягнення мети обстежено 133 практично здорових дітей (68 хлопців та 65 дівчат), які були розділені на чотири групи: 1-ша $(\mathrm{n}=33)$ - хлопці та дівчата із належним йодо- та залізозабезпеченням (контрольна група); 2-га (n=34) - школярі із обмеженим забезпеченням йоду (ЛЙ), 3-тя (n=32) - діти із латентним залізодефіцитом (Л3), 4-та $(\mathrm{n}=34)$ школярі із латентним залізодефіцитом та легким йододефіцитом (ЛЙ+ЛЗ). Аналізуючи досліджувані 
показники у кожній групі, звертали увагу на вікові (611 і 12-18 років) та гендерні особливості.

Тиреоїдний гомеостаз оцінювали за гормональним статусом та концентрацією йоду в сечі. У сироватці крові визначали вміст тиреоїдних гормонів: вільних трийодтироніну ( $\mathrm{fT}_{3}$ ) та тироксину (fT4), тиреотропного гормону аденогіпофізу (методом імуноферментного аналізу 3 використанням тест-наборів «DRG», Німеччина), у сечі - показники добової екскреції йоду [15]. Для оцінки транспортного фонду заліза у обстежених визначали вміст гемоглобіну $(\mathrm{Hb})$ у капілярній крові, рівень сироваткового заліза (C3) (колориметричним методом 3 використанням тест-набору «Cormay», Польща) загальну залізозв'язувальну здатність сироватки крові (33С) фотометричним методом (тест набір «Cormay», Польща) та розраховували коефіцієнт насичення трансферину залізом (КНТЗ). Стан депо заліза характеризували за рівнем сироваткового феритину (СФ), який визначали хемілюмінісцентним методом (тест набір «DRG», Німеччина) [10].

Для оцінки когнітивних функцій у школярів визначали IQ шляхом тестування за допомогою адаптованої на кафедрі фізіології ІваноФранківського національного медичного університету методики CFIT (Culture Free Intellect Test) P. Кеттела [3]; проводили коректурну пробу (визначали швидкість опрацювання інформації, коефіцієнти чіткості виконуваної роботи та стійкості уваги); досліджували показники темпу сенсорних реакцій та особливостей уваги (психічну стійкість, ефективність роботи, ступінь включення в роботу) за модифікованими таблицями Шульте [7].

Статистичну обробку даних проводили на основі пакету статистичних програм Microsoft Office Excel 2016 та STATISTICA 10.

Результати дослідження та їх обговорення. У результаті проведення дослідження до 1-ї та 3-ї дослідних груп були віднесені діти, у яких концентрація йоду в сечі перевищувала 100 мкг/л (характеризує належне йодозабезпечення). У 2-гу та 4-ту дослідну групу - діти із вмістом йоду в сечі від 70 до 100 мкг/л (характеризує наявність легкого йододефіциту) [6]. У результаті проведеного аналізу показників тиреоїдного статусу у дітей із легким йододефіцитом (2-га дослідна група) установлено зменшення вмісту $\mathrm{fT}_{3}$ на $18-19 \%,\left(\mathrm{p}_{1-2}<0,05\right)$ та $\mathrm{fT}_{4}$ на $14-16 \%, \quad\left(\mathrm{p}_{1-2}<0,05\right)$ щодо контрольних даних (3 урахуванням віку та статі). У школярів із комбіновани йодо- та залізодефіцитом (4-та дослідна група) установлено зменшення $\mathrm{fT}_{3}$ на $19-21 \%$, ( $\mathrm{p}_{1-}$ $\left.{ }_{4}<0,05\right) \quad$ та $\mathrm{fT}_{4} \quad$ (на $15-19 \%, \quad\left(\mathrm{p}_{1-4}<0,05\right)$ щодо контрольних даних (з урахуванням віку та статі). Такі зміни відбувалися на тлі зростання рівня ТТГ у крові дітей із ЛЙ на $74 \%\left(\mathrm{p}_{1-2}<0,05\right)-$ у 2,2 рази $\left(\mathrm{p}_{1-2}<0,001\right)$, а у школярів з ЛЙ та ЛЗ на $86 \%\left(\mathrm{p}_{1-4}<0,01\right)-$ у 2,7 рази $\left(\mathrm{p}_{1-4}<0,001\right)$, щодо аналогічних показників контрольної групи.

Характеризуючи обмін заліза, необхідно акцентувати, що у дітей 1-ї (контрольної) та 2-ї до- слідних груп вивчені показники знаходились у межах референтних даних. У всіх обстежених 3-ї дослідної групи вміст сироваткового заліза знаходився в межах 12-10 мкмоль/л, сироваткового феритину - 2012 нг/мл, загальна залізозв'язувальна здатність сироватки перевищувала 58 мкмоль/л. Такі дані підтверджують розвиток латентного залізодефіциту у дітей [10]. У результаті проведеного аналізу показників обміну заліза, у дітей із латентним залізодефіцитом (3-тя група) установлено зменшення вмісту $\mathrm{Hb}$ у капілярній крові на $13-16 \%\left(\mathrm{p}_{1-3}<0,05\right), \mathrm{C} 3$ - на 36-44 $\%\left(\mathrm{p}_{1-3}<0,01\right)$, СФ - на 39-51\% $\left(\mathrm{p}_{1-3}<0,05\right)$, КНТЗ - на $45-57 \%\left(\mathrm{p}_{1-3}<0,05\right)$ на тлі зростання 333С - на $27-$ $33 \%\left(\mathrm{p}_{1-3}<0,05\right)$ щодо даних у однолітків контрольної групи. За умов залізо- та йододефіциту зміни показників обміну заліза були більш суттєві, зокрема, виявлено достовірне зниження вмісту $\mathrm{Hb}$ у капілярній

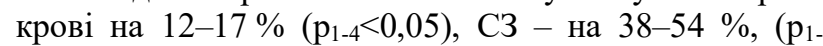
$\left.{ }_{4}<0,01\right)$, СФ - на 48-69 \% $\left(\mathrm{p}_{1-4}<0,01\right)$, КНТ3 - на 55$72 \%\left(\mathrm{p}_{1-4}<0,05\right)$ та збільшення 333С - на 36-60\% $\left(\mathrm{p}_{1-}\right.$ $\left.{ }_{4}<0,05\right)$ щодо контрольних даних.

При аналізі рівня розумового розвитку встановлено, що у дітей із легким йододефіцитом віком 6-11 років IQ коливався у хлопчиків у межах від 75 до 96 ум.од., а у дівчат - від 85 до 96 ум.од. У старшокласників цієї ж групи IQ в юнаків знаходився в межах від 88 до 103 ум.од., а у дівчат - від 87 до 100 ум.од. (табл.1). У $56 \%$ хлопчиків та у $67 \%$ дівчаток молодшого шкільного віку та у $12 \%$ дітей старшого віку IQ був меншим за 90 ум.од.

У дітей із латентним залізодефіцитом (у $38 \%$ хлопчиків та у $25 \%$ дівчат віком 6-11 років та у $12 \%$ дівчат 12-18 років) коефіцієнт інтелекту був меншим за 90 ум.од. При цьому у хлопчиків молодшого шкільного віку показник знаходився в межах від 85 до 95 ум.од., а у дівчат - від 88 до 97 ум.од.. У дітей старшого шкільного віку IQ у юнаків коливався в межах від 91 до 96 ум.од., а у дівчат - від 83 до 99 ум.од. (табл.1).

У дітей із комбінованим дефіцитом мікроелементів IQ був меншим за 90 ум.од. у $90 \%$ хлопчиків і $88 \%$ дівчат віком 6-11 років та у $63 \%$ юнаків і $50 \%$ дівчат $12-18$ років. Зокрема, IQ знаходився в межах від 71 до 92 ум.од. у хлопчиків та від 75 до 92 ум.од. у дівчаток молодшого віку, та від 80 до 92 ум.од. у юнаків і від 76 до 92 ум.од. у дівчат старшого шкільного віку (табл. 1).

В усіх дітей контрольної групи IQ був вищим за 90 ум.од. При цьому у $25 \%$ хлопчиків та $13 \%$ дівчаток віком 6-11 років та у $11 \%$ юнаків 12-18 років IQ перевищив 110 ум. од.

У результаті порівняльного аналізу у обстежених дітей із легким йододефіцитом та латентним залізодефіцитом виявлено достовірне зниження коефіцієнта IQ у хлопчиків на $19 \%\left(\mathrm{p}_{1-}\right.$ $\left.{ }_{4}<0,05\right)$ та у дівчаток - на $15 \%\left(\mathrm{p}_{1-4}<0,05\right)$ молодшого шкільного віку та у юнаків на $13 \%\left(\mathrm{p}_{1-4}<0,05\right)$ старшого шкільного віку щодо аналогічних значень контролю (табл. 1). Вірогідних розбіжностей даних IQ між віковими групами встановлено не було. 
Таблиця 1

Рівень коефіцієнта інтелекту (IQ) у дітей із належним обміном заліза та йоду (контрольна група), легким йододефіцитом, латентним залізодефіцитом та за умови їх посднання віком 6-18 років (M+m)

\begin{tabular}{|c|c|}
\hline Дослідні групи & IQ, ум.од \\
\hline \multicolumn{2}{|c|}{ Діти 6-11 років } \\
\hline $\begin{array}{l}\text { 1-ша (контрольна) } \\
\text { Хлопчики }(\mathrm{n}=8) \\
\text { Дівчатка }(\mathrm{n}=8) \\
\end{array}$ & $\begin{array}{c}100,1 \pm 5,63 \\
97,3 \pm 4,36 \\
\end{array}$ \\
\hline $\begin{array}{l}\text { 2-га (легкий йододефіцит) } \\
\text { Хлопчики }(\mathrm{n}=9) \\
\text { Дівчатка }(\mathrm{n}=9)\end{array}$ & $\begin{array}{l}87,6 \pm 5,52 \\
89,3 \pm 3,91 \\
\end{array}$ \\
\hline $\begin{array}{l}\text { 3-тя (латентний залізодефіцит) } \\
\text { Хлопчики }(\mathrm{n}=8) \\
\text { Дівчатка }(\mathrm{n}=8)\end{array}$ & $\begin{array}{l}90,6+3,20 \\
92,1+3,10\end{array}$ \\
\hline $\begin{array}{l}\text { 4-та (легкий йододефіцит та латентний залізодефіцит) } \\
\text { Хлопчики }(\mathrm{n}=10) \\
\text { Дівчатка }(\mathrm{n}=8)\end{array}$ & $\begin{array}{l}80,9 \pm 6,24 \\
\mathrm{p}_{1-4}<0,05 \\
82,7 \pm 4,08 \\
\mathrm{p}_{1-4}<0,05\end{array}$ \\
\hline \multicolumn{2}{|c|}{ Діти $12-18$ років } \\
\hline $\begin{array}{l}\text { 1-ша (контрольна) } \\
\text { Юнаки }(\mathrm{n}=9) \\
\text { Дівчата }(\mathrm{n}=8)\end{array}$ & $\begin{array}{l}98,7 \pm 2,89 \\
97,9 \pm 3,81\end{array}$ \\
\hline $\begin{array}{l}\text { 2-га (легкий йододефіцит) } \\
\text { Юнаки }(\mathrm{n}=8) \\
\text { Дівчата }(\mathrm{n}=8)\end{array}$ & $\begin{array}{l}95,3 \pm 5,28 \\
93,7 \pm 4,04\end{array}$ \\
\hline $\begin{array}{l}\text { 3-тя (латентний залізодефіцит) } \\
\text { Юнаки }(\mathrm{n}=8) \\
\text { Дівчата }(\mathrm{n}=8)\end{array}$ & $\begin{array}{l}93,4 \pm 3,77 \\
92,7 \pm 5,72\end{array}$ \\
\hline $\begin{array}{l}\text { 4-та (легкий йододефіцит та латентний залізодефіцит) } \\
\text { Юнаки }(\mathrm{n}=8) \\
\text { Дівчата }(\mathrm{n}=8)\end{array}$ & $\begin{array}{l}86,3 \pm 4,27 \\
\mathrm{p}_{1-4}<0,05 \\
86,3 \pm 5,68\end{array}$ \\
\hline
\end{tabular}

Примітка: р з арабськими цифрами - достовірна різниця між показниками у відповідних дослідних групах

За даними коректурної проби стійкість та інтенсивність роботи найвища у контрольній групі і найнижча - при комбінованому мікроелементозі.

У результаті порівняльного аналізу показників коректурної проби у дітей із легким йододефіцитом віком 6-11 років встановили, що коефіцієнт стійкості уваги (V) був меншим на $29 \%\left(\mathrm{p}_{1-2}<0,05\right)$ у хлопців та на $39 \%\left(\mathrm{p}_{1-2}<0,05\right)$ у дівчат, швидкість опрацювання інформації (C) - на $45 \%\left(\mathrm{p}_{1-2}<0,01\right)$ у дівчат щодо аналогічних показників контрольної групи. У дітей із латентним залізодефіцитом виявили зменшення С у дівчат на $32 \%\left(\mathrm{p}_{1-3}<0,05\right)$ щодо контролю. У школярів із легким йододефіцитом та латентним залізодефіцитом виявили зменшення $\mathrm{V}$ y хлопців на $29 \%\left(\mathrm{p}_{1-4}<0,05\right)$ та у дівчат на $42 \%$ $\left(\mathrm{p}_{1-4}<0,01\right), \mathrm{C}-$ на $46 \%\left(\mathrm{p}_{1-4}<0,01\right)$ тільки у дівчат щодо контрольних даних (табл. 2). У дітей старшої вікової групи достовірну розбіжність між показниками установлено тільки у дівчат із легким йододефіцитом (С був меншим на $30 \%, \mathrm{p}_{1-2}<0,05$ щодо контролю).

3 віком достовірно збільшувались коефіцієнти $\mathrm{V}$ та С у хлопців 3 легким йододефіцитом - на 57 $\%(\mathrm{p}<0,05)$, обидва показники, та у дівчат із легким йододефіцитом та латентним залізодефіцитом - на 44 і $43 \%$ (p<0,05) відповідно (табл. 2).

Також встановлено, що у дівчат контрольної групи молодшого шкільного віку була достовірно більша швидкість опрацювання інформації (на 42 \%, $\mathrm{P}<0,05)$ щодо значень у хлопчиків. 
Таблиця 2

Показники коректурної проби дітей із належним обміном заліза та йоду (контрольна група), легким йододефіцитом, латентним залізодефіцитом та за умов їх посднання віком 6-18 років (M士m)

\begin{tabular}{|c|c|c|c|}
\hline \multirow[t]{2}{*}{ Дослідні групи } & \multirow{2}{*}{$\begin{array}{l}\text { Показ- } \\
\text { ники }\end{array}$} & \multicolumn{2}{|c|}{ Середні значення за 5 хв } \\
\hline & & 6-11 років & 12-18 років \\
\hline $\begin{array}{l}\text { 1-ша (контрольна) } \\
\text { Хлопці }(\mathrm{n}=17) \\
\text { Дівчата }(\mathrm{n}=16)\end{array}$ & $\begin{array}{l}\mathrm{K} \\
\mathrm{V} \\
\mathrm{C} \\
\mathrm{K} \\
\mathrm{V} \\
\mathrm{C}\end{array}$ & $\begin{array}{l}0,90 \pm 0,06 \\
126,1 \pm 12,4 \\
25,4 \pm 2,67 \\
0,90 \pm 0,05 \\
154,9 \pm 16,0 \\
36,0 \pm 3,26 \quad \mathrm{P}<0,05\end{array}$ & $\begin{array}{l}0,92 \pm 0,04 \\
154,4 \pm 14,9 \\
32,7 \pm 3,61 \\
0,92 \pm 0,06 \\
164,4 \pm 16,9 \\
37,8 \pm 4,03\end{array}$ \\
\hline $\begin{array}{l}\text { 2-га (легкий йододефіцит) } \\
\text { Хлопці }(\mathrm{n}=17) \\
\text { Дівчата }(\mathrm{n}=17)\end{array}$ & $\begin{array}{l}\mathrm{K} \\
\mathrm{V} \\
\mathrm{C} \\
\mathrm{K} \\
\mathrm{V} \\
\mathrm{C}\end{array}$ & $\begin{array}{l}0,84 \pm 0,06 \\
89,1 \pm 9,52 \mathrm{p}_{1-2}<0,05 \\
18,6 \pm 2,01 \\
0,83 \pm 0,06 \\
95,1 \pm 9,64 \mathrm{p}_{1-2}<0,05 \\
19,9 \pm 2,28 \mathrm{p}_{1-2}<0,01\end{array}$ & $\begin{array}{l}0,88 \pm 0,06 \\
139,5 \pm 13,5^{*} \\
29,2 \pm 3,54^{*} \\
0,88 \pm 0,08 \\
126,4 \pm 12,5 \\
26,4 \pm 1,93 \mathrm{p}_{1-2}<0,05\end{array}$ \\
\hline $\begin{array}{l}\text { 3-тя (латентний залізодефіцит) } \\
\text { Хлопці }(\mathrm{n}=16) \\
\text { Дівчата }(\mathrm{n}=16)\end{array}$ & $\begin{array}{l}\mathrm{K} \\
\mathrm{V} \\
\mathrm{C} \\
\mathrm{K} \\
\mathrm{V} \\
\mathrm{C}\end{array}$ & $\begin{array}{l}0,86 \pm 0,08 \\
111,0 \pm 11,3 \\
23,8 \pm 3,2 \\
0,95 \pm 0,04 \\
119,1 \pm 11,7 \\
24,6 \pm 2,75 \quad \mathrm{p}_{1-3}<0,05\end{array}$ & $\begin{array}{l}0,93 \pm 0,07 \\
130,1 \pm 13,5 \\
27,8 \pm 3,3 \\
0,86 \pm 0,07 \\
130,7 \pm 13,6 \\
28,06 \pm 3,08\end{array}$ \\
\hline $\begin{array}{l}\text { 4-та (легкий йододефіцит, латентний } \\
\text { залізодефіцит) } \\
\text { Хлопці }(\mathrm{n}=18) \\
\text { Дівчата }(\mathrm{n}=16)\end{array}$ & $\begin{array}{l}\mathrm{K} \\
\mathrm{V} \\
\mathrm{C} \\
\mathrm{K} \\
\mathrm{V} \\
\mathrm{C}\end{array}$ & $\begin{array}{l}0,84 \pm 0,08 \\
89,6 \pm 9,22 \quad \mathrm{p}_{1-4}<0,05 \\
19,1 \pm 2,4 \\
0,81 \pm 0,08 \\
90,0 \pm 9,42 \quad \mathrm{p}_{1-4}<0,01 \\
19,4 \pm 2,07 \quad \mathrm{p}_{1-4}<0,01\end{array}$ & $\begin{array}{l}0,92 \pm 0,06 \\
123,7 \pm 12,39 \\
25,8 \pm 2,85 \\
0,87 \pm 0,06 \\
129,8 \pm 13,1^{*} \\
27,7 \pm 2,96^{*}\end{array}$ \\
\hline
\end{tabular}

Примітка: К - коефіцієнт точності виконуваної роботи, V - коефіцієнт стійкості уваги; С - швидкість опрацювання інформації; Р з арабськими цифрами - достовірна різниця між показниками у відповідних дослідних групах; Р - достовірні статеві відмінності; *- достовірні зміни між відповідними віковими групами $(\mathrm{p}<0,05)$

Динаміка показників коефіцієнта стійкості уваги, швидкості опрацювання інформації у обстежених різних дослідних груп представлена відповідно на рисунках 1, 2.

Темп сенсомоторних реакцій і особливостей уваги досліджували за допомогою таблиць Шульте (табл. 3). У дітей 6-11 років виявили достовірне зниження ефективності роботи (ЕР) у дівчат з легким йододефіцитом на $41 \%\left(\mathrm{p}_{1-2}<0,05\right)$ та при комбінованому мікроелементозі - у хлопців на $37 \%\left(\mathrm{p}_{1-4}<0,05\right)$, у дівчат - на $48 \%\left(\mathrm{p}_{1-4}<0,05\right)$ щодо контрольних даних.

У дітей старшого шкільного віку спостерігали достовірне зниження ЕР тільки у юнаків при йодо- та залізодефіциті (на $\left.35 \%, \mathrm{p}_{1-4}<0,05\right)$ щодо контролю. У дітей даної вікової категорії також виявили достовірне зростання ступеня включення в роботу (ВкР) у юнаків із легким йододефіцитом - на $22 \%\left(\mathrm{p}_{1-2}<0,05\right)$ та у дівчат із комбінованим мікро- елементозом - на $32 \%\left(\mathrm{p}_{1-4}<0,05\right)$ щодо контрольних даних (табл. 3).

Характеризуючи динаміку показників, у обстежених контрольної групи переважала крива виснаження по гіпостенічному типу незалежно від вікових та гендерних особливостей. У дітей із легким йододефіцитом віком 6-11 років переважала крива виснаження по гіпостенічному типу, а у старших школярів - по гіперстенічному типу. У дітей із латентним залізодефіцитом віком 6-11 років крива виснаження була нестійкою у $50 \%$, гіпо- та гіперстенічною - у $25 \%$, а у старших школярів - у 24 \% - нестійкою і по 38 \% - гіпо- та гіперстенічною. У дітей iз легким йододефіцитом та латентним залізодефіцитом віком 6-11 років крива виснаження у хлопчиків та дівчат була відповідно нестійкою у 50 і $25 \%$, гіперстенічною - у 25 і $37 \%$ та гіпостенічною у 25 і $37 \%$; у старшокласників незалежно від статі у $50 \%$ гіперстенічною, по $25 \%$ - гіпостенічною чи нестійкою (рис. 3). 


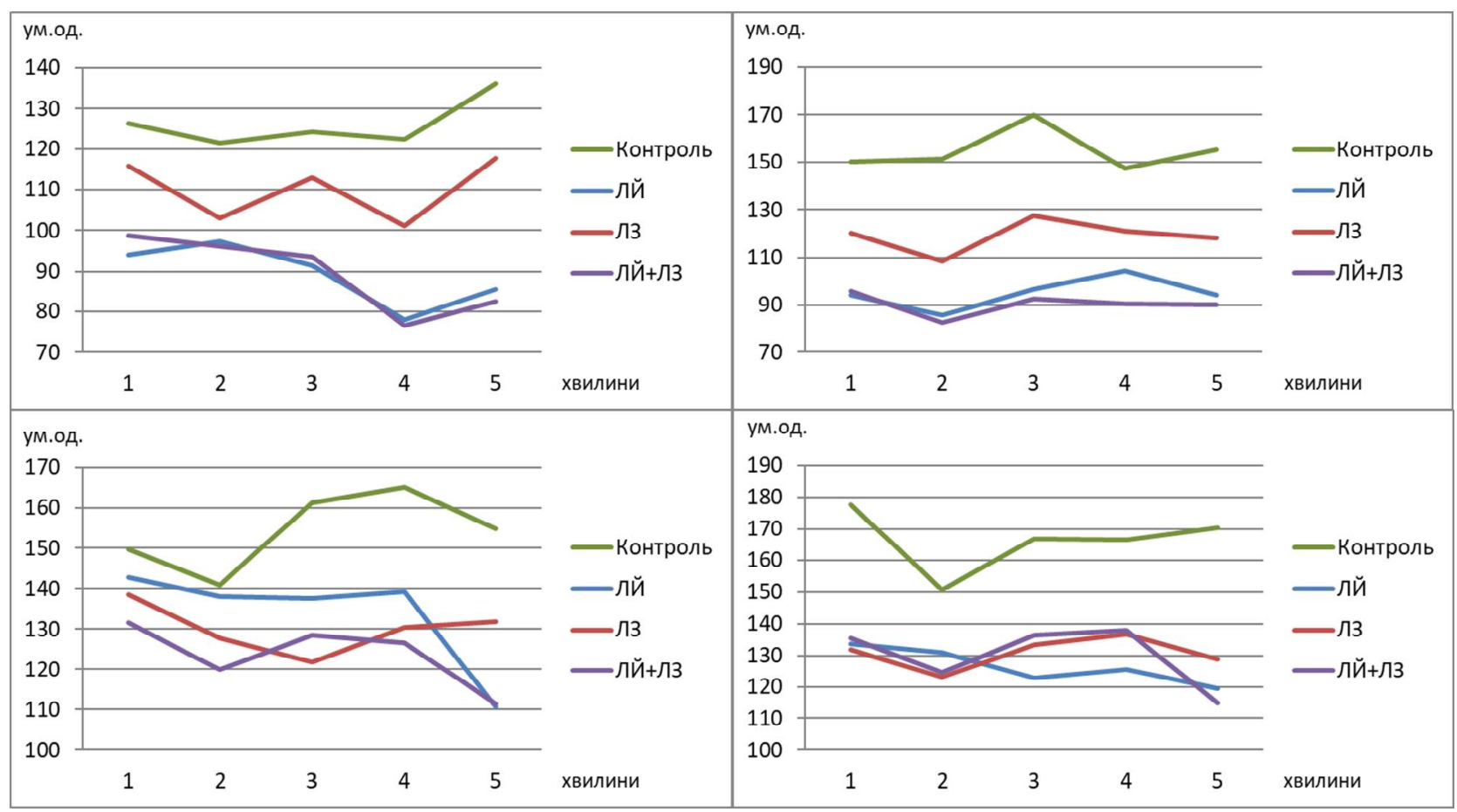

Рис. 1. Динаміка зміни коефіцієнта стійкості уваги (V) у дітей із належним обміном заліза та йоду (контрольна група), легким йододефіцитом (ЛЙ), латентним залізодефіцтом (ЛЗ) та за умови їх при посднання (ЛЙ+ЛЗ) віком 6-11 (у хлопчиків - а та у дівчаток - б), 12-18 років (у юнаків - в та у дівчат - г)

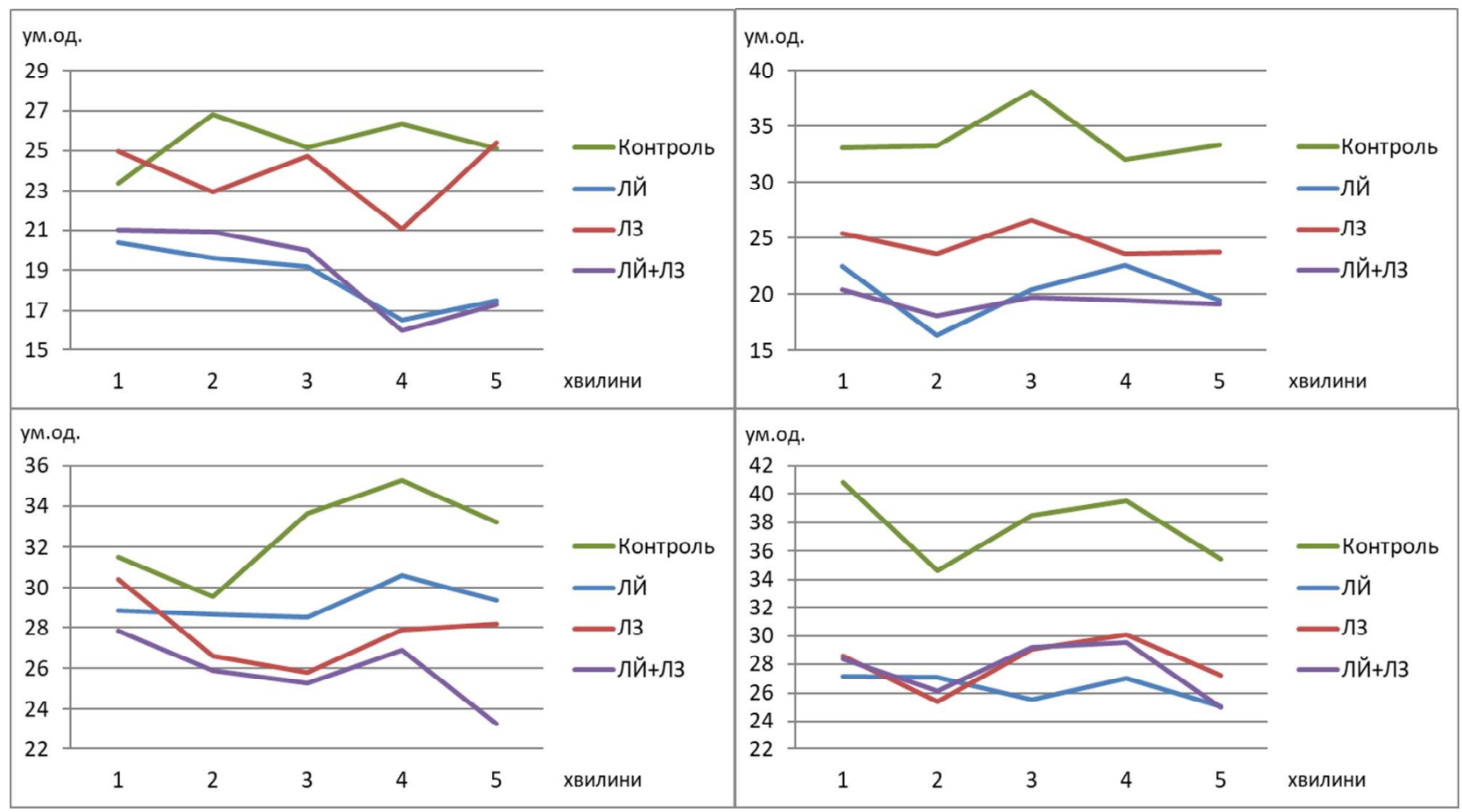

Рис. 2. Динаміка зміни швидкості опрацювання інформації (C) у дітей із належним обміном заліза та йоду (контрольна група), легким йододефіцитом (ЛЙ), латентним залізодефіцтом (ЛЗ) та за умови їх при посднання (ЛЙ+ЛЗ) віком 6-11 (у хлопчиків - а та у дівчаток - б), 12-18 років (у юнаків - в та у дівчат - г) 
Таблиця 3

Показники темпу сенсорних реакцій та особливостей уваги

(за модифікованими таблицями Шульте) дітей 6-18 років із легким йододефіцитом (Лй), латентним залізодефіцитом (ЛЗ), при поєднанні йодо- і залізодефіциту (ЛЙ+ЛЗ) та в контрольній групі (М七m)

\begin{tabular}{|c|c|c|c|c|c|c|c|c|}
\hline \multirow{3}{*}{ Показники } & \multicolumn{2}{|c|}{$\begin{array}{c}\text { 1-ша дослідна група } \\
\text { (контрольна) }\end{array}$} & \multicolumn{2}{|c|}{$\begin{array}{c}\text { 2-га дослідна група } \\
\text { (ЛЙ) }\end{array}$} & \multicolumn{2}{|c|}{$\begin{array}{c}\text { 3-тя дослідна група } \\
\text { (Л3) }\end{array}$} & \multicolumn{2}{|c|}{$\begin{array}{c}\text { 4-та дослідна група } \\
\text { (ЛЙ+ЛЗ) }\end{array}$} \\
\hline & \multicolumn{8}{|c|}{ Діти віком 6-11 років } \\
\hline & $\begin{array}{c}\text { Хлопчики } \\
(\mathrm{n}=8)\end{array}$ & $\begin{array}{c}\text { Дівчатка } \\
(\mathrm{n}=8)\end{array}$ & $\begin{array}{c}\text { Хлопчики } \\
(\mathrm{n}=9)\end{array}$ & $\begin{array}{c}\text { Дівчатка } \\
(\mathrm{n}=9)\end{array}$ & $\begin{array}{c}\text { Хлопчики } \\
(\mathrm{n}=8)\end{array}$ & $\begin{array}{c}\text { Дівчатка } \\
(\mathrm{n}=8)\end{array}$ & $\begin{array}{c}\text { Хлопчики } \\
(\mathrm{n}=10)\end{array}$ & $\begin{array}{c}\text { Дівчатка } \\
(\mathrm{n}=8)\end{array}$ \\
\hline $\begin{array}{l}\text { Ефективність } \\
\text { роботи (ЕР) }\end{array}$ & $2,63 \pm 0,35$ & $3,14 \pm 0,52$ & $1,87 \pm 0,34$ & $\begin{array}{l}1,85 \pm 0,21 \\
\mathrm{p}_{1-2}<0,05\end{array}$ & $2,00 \pm 0,25$ & $2,63 \pm 0,31$ & $\begin{array}{l}1,66 \pm 0,22 \\
\mathrm{p}_{1-4}<0,05\end{array}$ & $\begin{array}{l}1,63 \pm 0,37 \\
\mathrm{p}_{1-4}<0,05\end{array}$ \\
\hline $\begin{array}{l}\text { Ступінь } \\
\text { включення в } \\
\text { роботу (ВкР) }\end{array}$ & $0,84 \pm 0,10$ & $0,91 \pm 0,11$ & $0,95 \pm 0,10$ & $0,92 \pm 0,11$ & $0,92 \pm 0,08$ & $0,94 \pm 0,09$ & $0,84 \pm 0,10$ & $0,99 \pm 0,12$ \\
\hline \multirow[t]{3}{*}{$\begin{array}{l}\text { Психічна } \\
\text { стійкість ПС) }\end{array}$} & $1,09 \pm 0,04$ & $1,04 \pm 0,05$ & $1,00 \pm 0,10$ & $1,03 \pm 0,06$ & $1,07 \pm 0,05$ & $0,97 \pm 0,08$ & $1,07 \pm 0,11$ & $1,03 \pm 0,12$ \\
\hline & \multicolumn{8}{|c|}{ Діти віком 12-18 років } \\
\hline & $\begin{array}{c}\text { Юнаки } \\
(n=9)\end{array}$ & $\begin{array}{c}\text { Дівчата } \\
(\mathrm{n}=8)\end{array}$ & $\begin{array}{c}\text { Юнаки } \\
(n=8)\end{array}$ & $\begin{array}{c}\text { Дівчата } \\
(\mathrm{n}=8)\end{array}$ & $\begin{array}{c}\text { Юнаки } \\
(\mathrm{n}=8)\end{array}$ & $\begin{array}{c}\text { Дівчата } \\
(\mathrm{n}=8)\end{array}$ & $\begin{array}{c}\text { Юнаки } \\
(n=8)\end{array}$ & $\begin{array}{c}\text { Дівчата } \\
(\mathrm{n}=8)\end{array}$ \\
\hline $\begin{array}{l}\text { Ефективність } \\
\text { роботи (ЕР) }\end{array}$ & $3,33 \pm 0,41$ & $3,0 \pm 0,40$ & $2,66 \pm 0,30$ & $2,4 \pm 0,42$ & $2,52 \pm 0,33$ & $3,25 \pm 0,41$ & $\begin{array}{c}2,16 \pm 0,28 \\
\mathrm{p}_{1-4}<0,05\end{array}$ & $2,5 \pm 0,28$ \\
\hline $\begin{array}{l}\text { Ступінь } \\
\text { включення в } \\
\text { роботу (ВкР) }\end{array}$ & $0,86 \pm 0,04$ & $0,85 \pm 0,06$ & $\begin{array}{l}1,05 \pm 0,07 \\
\mathrm{p}_{1-2}<0,05\end{array}$ & $1,08 \pm 0,19$ & $0,97 \pm 0,03$ & $0,95 \pm 0,08$ & $0,99 \pm 0,09$ & $\begin{array}{l}1,12 \pm 0,10 \\
\mathrm{p}_{1-4}<0,05\end{array}$ \\
\hline $\begin{array}{l}\text { Психічна } \\
\text { стійкість ПС) }\end{array}$ & $1,11 \pm 0,04$ & $1,07 \pm 0,04$ & $1,01 \pm 0,10$ & $0,97 \pm 0,09$ & $1,05 \pm 0,06$ & $1,06 \pm 0,03$ & $1,05 \pm 0,18$ & $0,95 \pm 0,10$ \\
\hline
\end{tabular}
пах.

Примітка: Р з арабськими цифрами - достовірна різниця між показниками у відповідних дослідних гру-

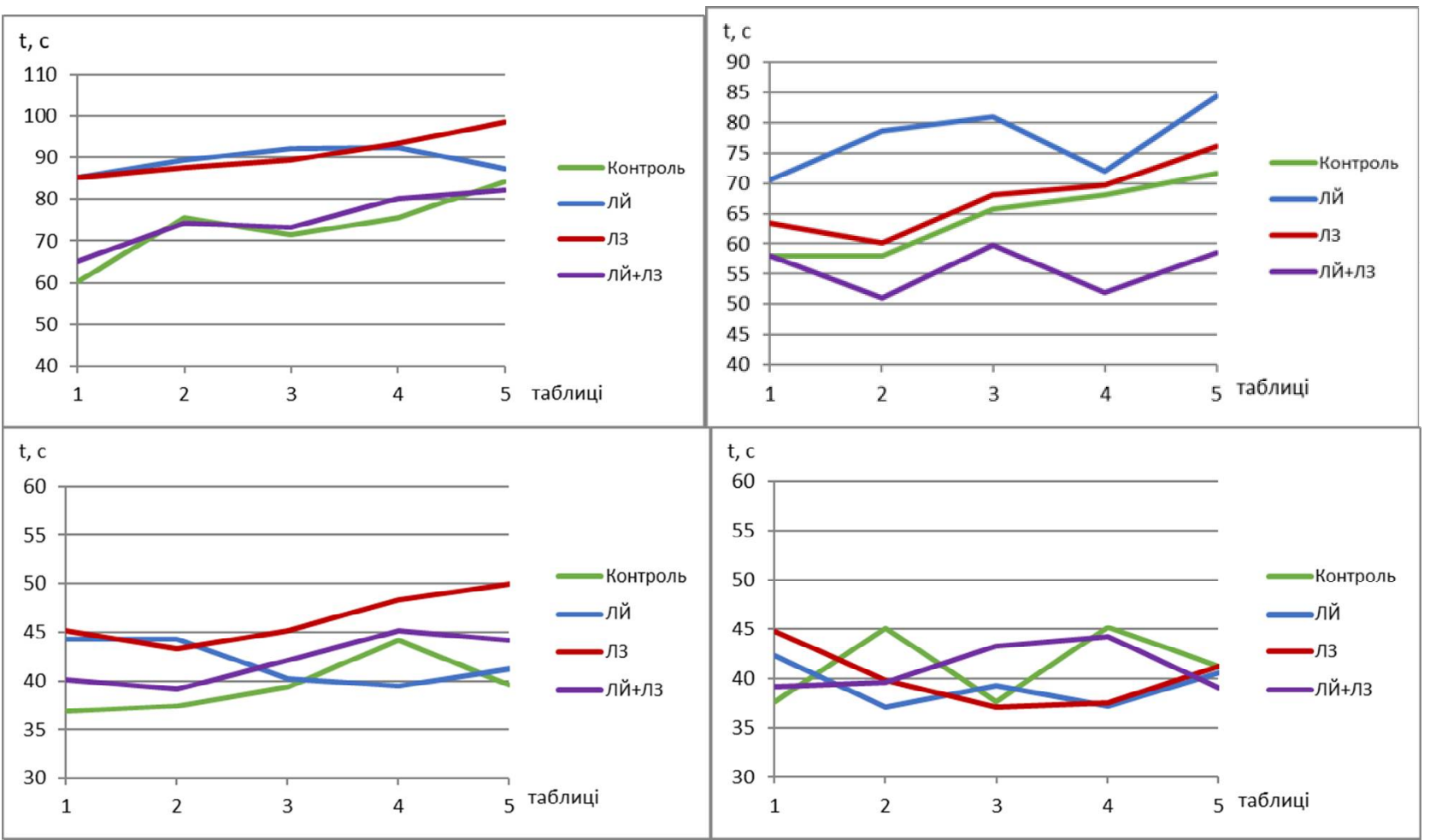

Рис. 3. Крива виснаження (за таблицями Шульте) у дітей із належним обміном заліза та йоду (контрольна група), із легким йододефіцитом (ЛЙ), латентним залізодефіцитом (ЛЗ) та за умови їх поєднання (ЛЙ+ЛЗ) віком 6-11 (у хлопчиків - а та у дівчаток - б), 12-18 років (у юнаків - в та у дівчат - г) 
Висновки. Дефіцит йоду та заліза негативно впливає на когнітивні функції дітей, що проявляється зменшенням коефіцієнта інтелекту, зниженням стійкості уваги, ефективності роботи, ступеня включення в роботу, швидкості опрацювання інформації та зростанням кількості дітей із нестійкою кривою виснаження. Ступінь порушення залежить від віку (більш чутливі молодші школярі), статі (більш чутливі дівчата) та генезу мікроелементозу (суттєвіші порушення виявленні при комбінованому мікроелементозі).

\section{References:}

1. Berezhnoi VV, Mamenko ME. Intellekt rebenka $\mathrm{i}$ yodnyy defytsyt: mekhanizmy nehatyvnoho vlyianyia i puti profylaktiki. Mezhdunarodnyy endokrynolohicheskiy zhurnal. 2014; 6:41-5.

2. Belukh NA. Prohnozyrovanye ryska formirovaniya hypofyzarno-tireoydnoi dezadaptatsyi $\mathrm{V}$ rehyone umerennoho yodnoho defitsyta. Mizhnarodnyi zhurnal pediatrii, akusherstva i hinekolohii. 2017; 11(2):28-35.

3. Vitenko IS, Voronych-Semchenko NM, Yemelianenko IV, Botsiurko VI. Testy dlia vyznachennia intelektualnoho rozvytku ditei ta doroslykh. Navchalnometodychnyy posibnyk dlia likariv ta studentiv. IvanoFrankivsk: Nova Zoria; 2002. P.107.

4. Voronych-Semchenko NM, Varunkiv SV, Semchenko VA, Voronych VO. Zminy kohnityvnykh funktsii shkoliariv za umov yododefitsytu. Halytskyi likarskyi visnyk. 2016; 23(2):10-2.

5. Zakharova YN, Machneva EB. Defytsyt zheleza u podrostkov i eho korrektsyia preparatami zheleza. Sovremennaia pedyatryia. 2016; 1:11-6.

6. Mamenko MIe, Shlieienkova HO, Dontsova KM. Vplyv saplimentatsii yodu na fizychnyi, nervovopsykhichnyi rozvytok ta nevrolohichnyi status ditey rannoho viku. Sovremennaia pedyatryia. 2017; 1(81):13-9.

7. Menshykh OE, Petrenko YuO. Osoblyvosti psykhofiziolohichnykh funktsii uchniv starshoho shkilnoho viku. Cherkasy: ChNU im. Bohdana Khmelnytskoho; 2015.176s.

8. Mokiia-Serbina SO, Chechel VV. Stan kohnityvnoi sfery u ditey 5-6 richnoho viku z alimentarnym defitsytom zaliza. Klinichna medytsyna. 2014; 19(14):927.

9. Oleksiychuk NV, Perih YuS, Tytova TA. Doslidzhennia yododefitsytu u ditey shkilnoho viku. Biblioteka simeinoho likaria ta simeinoi medsestry. 2017; 2:38-9.

10. Salakh AA, Abushanova OV, Kucher OV. Suchasni pidkhody do laboratornoi diahnostyky zalizodefitsytnoi anemii. Siemeinaia medytsyna. 2014; 1(51):134-42.

11. Banadyha NV. Influence of iron deficiency anemia of the formation of systemic immunity in children. Journal of Education, Health and Sport. 2016; 6(1):93-100.

12. Cusick SE, Georgieff MK, Rao R. Approaches for reducing the risk of early-life iron deficiency-induced brain dysfunction in children. J. Nutr 2018; 10(2):227-41. 13. Leonard AJ, Chalmers KA, Collins CE, Patterson AJ. A study of the effects of latent iron deficiency on measures of cognition: a pilot randomised controlled trial of iron supplementation in young women. Nutrients 2014; 6:2419-35.

14. Metwalley KA, Farghaly HS, Hassan AF. Thyroid status in Egyptian primary school children with iron deficiency anemia: Relationship to intellectual function. Thyroid Res Pract. 2013; 10:91-5.

15. Zimmermann MB, Boelaert K. Iodine deficiency and thyroid disorders. Lancet Diabetes Endocrinol. 2015; 3(4):286-95.

\section{УДК 612.66+612.821.2+613.955+612.392.4+546.15 \\ ВОЗРАСТНЫЕ И ГЕНДЕРНЫЕ ОСОБЕННО- СТИ КОГНИТИВНЫХ ФУНКЦИЙ У ДЕТЕЙ ШКОЛЬНОГО ВОЗРАСТА С ЛЁГКИМ ЙОДОДЕФИЦИТОМ И ЛАТЕНТНЫМ ЖЕЛЕЗОДЕФИЦЫТОМ}

\section{У.П. Шаламай}

Ивано-Франковский национальный медицинский университет, кафедра физиологии,

г. Ивано-Франковск, Украина,

ORCIDID: 0000-0001-7044-3585,

e-mail:fap12710@gmail.com

Резюме. Актуальность исследования обусловлена распространенностью йодо- и железодефицитных состояний в Украине. Недостаток железа в раннем детстве приводит к задержке речевых навыков, снижению коэффициента интеллекта (IQ), способности к обучению. В подростковом возрасте дефицит железа сопровождается ухудшением памяти, адаптационных возможностей ЦНС. Недостаточное содержание йода в рационе питания обусловливает нарушение тиреоидного гомеостаза, особенно в детском возрасте, которое приводит к задержке психического и физического развития детей. В статье представлены результаты исследования психофизиологического развития 133 школьников в возрасте 6-18 лет с должным йодо- и железообеспечением (контрольная группа), латентным железодефицытом, лёгким йододефицитом и в условиях их сочетания. Для оценки когнитивных функций у школьников определяли коэффициент интеллекта, проводили корректурную пробу (определяли скорость обработки информации, коэффициент точности выполняемой работы и устойчивость внимания), исследовали показатели темпа сенсорных реакций и особенностей внимания (психическую устойчивость, эффективность работы, степень включения в работу) по модифицированным таблицам Шульте.

Установлено, что дефицит микроэлементов (железа и йода) приводит к нарушению когнитивных функций, особенно при комбинированном их воздействии. У таких детей установлено снижение коэффициента интеллекта у $74 \%$ обследованных (ниже 90 усл. ед.), эффективности работы на $48 \%(\mathrm{p}<0,05)$, степени включения в работу на $32 \%(\mathrm{p}<0,05)$, скорости обработки информаций на $46 \%(\mathrm{p}<0,01)$, коэффициента устойчивости внимания на $36 \%(\mathrm{p}<0,05)$ и увеличение количества детей с неустойчивой кривой истощения. Степень психофизиологических наруше- 
ний зависит от возраста (более чувствительны младшие школьники), пола (более склонны девушки) и генеза микроэлементозов (существенные нарушения обнаружены при комбинированном йодо- и железодефиците).

Ключевые слова: когнитивные функции, латентный железодефицит, легкий йододефицит, дети школьного возраста.

\section{UDC 612.66+612.821.2+613.955+612.392.4+546.15 \\ AGE AND GENDER PECULIARITIES OF COGNI- TIVE FUNCTIONS IN SCHOOL-AGED CHILDREN WITH MILD IODINE DEFICIENCY AND LATENT IRON DEFICIENCY}

\author{
U.P. Shalamay
}

Ivano-Frankivsk National Medical University, Department of Physiology, Ivano-Frankivsk, Ukraine, ORCID ID: 0000-0001-7044-3585, e-mail:fap12710@gmail.com

Abstract. The relevance of the study is due to the prevalence of iodine and iron deficiency in Ukraine. Lack of iron in early childhood leads to a delay in language skills, a decrease of intelligence quotient (IQ), and learning ability. In adolescence, iron deficiency is accompanied by memory impairment and CNS adaptive capacities. Insufficient iodine content in the diet leads to the disorders of thyroid homeostasis, especially in childhood, which leads to the retention in the mental and physical development of children. More than 2/3 of children living in regions with environmental iodine deficiency, have intellectual disabilities (IQ is $10-15$ points lower than peers without iodine deficiency). Taking into account the prevalence of iodine and iron deficiency in Ukraine, it is advisable to study their combined effect on the cognitive functions of school-aged children.

The aim of the research is to study the effect of mild iodine deficiency and latent iron deficiency on the cognitive function of school-aged children.

The article represents the results of a study of the psychophysiological development of 133 schoolchildren aged 6-18 years with appropriate iodine and iron support (control group), latent iron deficiency, mild io- dine deficiency and in the conditions of their combination. Analyzing the studied indices in each group, the attention was paid to the age (6-11 and 12-18) and gender peculiarities. Thyroid homeostasis was evaluated according to hormonal status, iodine concentration in urine and thyroid ultrasound examination. Thyroid hormone content was determined in the blood serum: free triiodothyronine $\left(\mathrm{fT}_{3}\right)$ and thyroxine $\left(\mathrm{fT}_{4}\right), \mathrm{TSH}$ of the adenohypophysis; in urine - indices of daily iodine excretion. The hemoglobin content in the capillary blood, serum iron level, total iron binding capacity of blood serum, and transferrin iron saturation coefficient were calculated to evaluate iron depot transport in the examined patients. The condition of iron depot was characterized by the serum ferritin level. To evaluate the cognitive functions in schoolchildren there were determined the intelligence quotient, a corrective test was performed (the speed of processing information, the coefficients of accuracy of performed work and stability of attention were determined), the indices of the rate of sensory reactions and peculiarities of attention (psychological stability, work efficiency, degree of work worming-up) were studied according to the modified tables of Schulte.

It is determined that deficiency of trace elements (iron and iodine) causes impaired cognitive functions, especially when their influence is combined. In children with mild iodine deficiency and latent iron deficiency there was determined a significant decrease of IQ in boys at $19 \%$ and in girls at $15 \%$ in primary school age, and in adolescents at $13 \%$ older school age as for similar control values. In this group of the studied there was found: a $37 \%$ decrease of work efficiency in boys, and at $48 \%$ in younger girls, and at $35 \%$ in older aged boys; a $32 \%$ decrease of the degree of work warming-up in girls; information processing speed at $46 \%$ in girls, at $29 \%$ stability of attention in boys and at $42 \%$ in girls aged 6-11 years as for similar control values. In the combined microelementosis the number of children with unstable exhaustion curve increases. The degree of impairment depends on the age (more sensitive younger children), gender (more sensitive girls) and genesis of microelementosis (more severe abnormalities were found in combined microelementosis).

Keywords: cognitive functions, latent iron deficiency, mild iodine deficiency, school-aged children. 